\title{
Analysis of Crosstalk Noise Using Graphene Nanoribbon Interconnects by Changing Wire Spacing and Electron Mean Free Path
}

\author{
S. Bhattacharya1,*, S. Das², S. Tayal ${ }^{1}$, J. Ajayan¹, L.M.I. Leo Joseph¹, D. Das ${ }^{3}$ \\ 1 Department of Electronics and Communication Engineering, SR University, Warangal, Telangana, India \\ 2 School of VLSI Technology, Indian Institute of Engineering Science and Technology, Shibpur, India \\ ${ }_{3}^{3}$ Department of Electronics and Communication Engineering, Assam University, Silchar, India
}

(Received 10 October 2021; revised manuscript received 16 December 2021; published online 20 December 2021)

\begin{abstract}
In this article, we study the coupling capacitance $\left(C_{C}\right)$ and its effects on crosstalk noise in next generation high performance on-chip nano-integrated circuits by changing wire spacing and electron mean free path (MFP) between two neighboring nets using graphene nanoribbon (GNR) interconnects. For coupling capacitance analysis, three multilayer graphene nanoribbon (MLGNR) interconnects with different wire spacing (variation between 10 to $300 \mathrm{~nm}$ ) and different interconnect length $(100,200$ and $300 \mu \mathrm{m})$ are considered. It is observed that a smaller separation gap between two neighboring nets shows $4-6 \times$ higher coupling capacitance compared to a larger wire spacing. In terms of mean free path (MFP), a higher MFP shows $20-34 \%$ less coupling capacitance compared to a lower MFP. In crosstalk noise analysis, a triinterconnect model with a driver load circuit (i.e., a CMOS inverter circuit with aggressor and victim net) is used to study the performance of GNR interconnects in terms of noise peak with different possible input combinations. It is also observed that the higher MFP of the MLGNR interconnect shows less noise peak $(1.11 \mathrm{mV}$ with $1200 \mathrm{~nm}$ MFP), whereas the lower MFP shows higher noise peak (3.65 mV with $300 \mathrm{~nm}$ MFP). This analysis is useful for area-efficient and noise-immune next generation high-speed integrated circuit design using GNR interconnects.
\end{abstract}

Keywords: Graphene nanoribbon (GNR), Mean free path (MFP), Interconnects, Temperature, Crosstalk.

DOI: 10.21272/jnep.13(6).06031

PACS numbers: 81.05.Uw, 63.22.Np, 61.46.Np

\section{INTRODUCTION}

Wire spacing in nanometer dimension for next generation high speed integrated circuit design is one of the challenging research areas [1]. Decreasing the wire spacing between two neighboring nets can cause crosstalk noise due to increased coupling capacitance [2, 3]. Similarly, increasing wire spacing between two neighboring nets can reduce the crosstalk effect, but it will require more on-chip area, which is contrary to Moore's law $[4,5]$. As a result, we need to think about some compromise in wire spacing between two neighboring nets for next generation advance, low power and highspeed integrated circuit design. Current studies show that multilayer graphene nanoribbon (MLGNR) interconnects are one of the most promising materials for modeling interconnects because they exhibit some remarkable properties over traditional interconnect materials (for example, $\mathrm{Cu}, \mathrm{Al}, \mathrm{Ni}$, etc.) [6-10]. It is a stack of single layer GNR (SLGNR) structures. It is a highly stable material with a wide temperature range $(\sim 30$ to $500 \mathrm{~K})$ and $40 \times$ harder than diamonds. It demonstrates high current conduction capability $\sim 10 \times$ higher than $\mathrm{Cu}$ nanomaterials and is highly immune to noise in nanoelectronic circuits. MLGNR interconnect also suppresses crosstalk noise with closed spacing between two neighboring nets compared to other nanomaterials. In this work, we mainly investigated crosstalk noise between two MLGNR interconnects placed in parallel using wire spacing variation and electron mean free path (MFP) variation. Cross-coupling capacitance $\left(C_{C}\right)$ is measured with different wire spacing and different
MFP. This coupling capacitance $\left(C_{C}\right)$ is the main source of noise in nanoelectronic circuits.

The rest of the paper is organized as follows. Section 2 represents the interconnect model for noise calculation. Section 3 presents the results and discussion. The conclusions are given in Section 4.

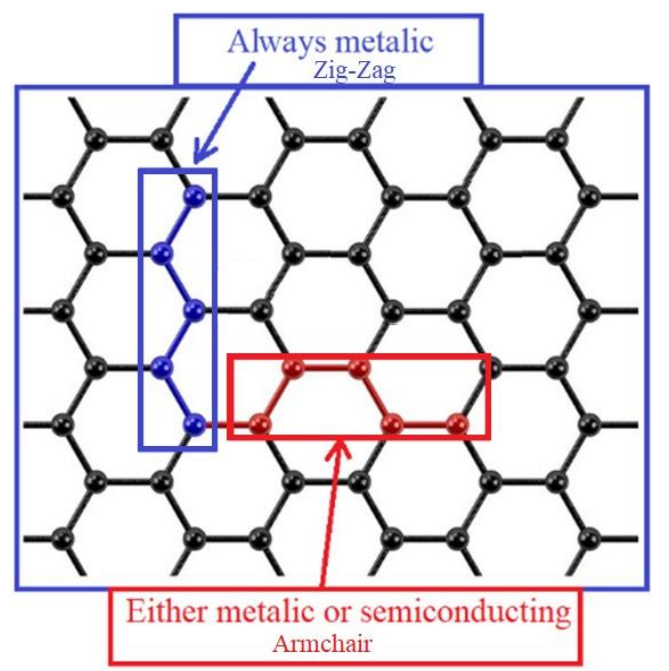

Fig. 1 - Schematic representation of a graphene sheet with Zigzag (metallic) and Armchair (either metallic or semiconducting) nanostructures

\section{INTERCONNECT MODEL}

Fig. 1 shows one graphene sheet of atomic thickness with a two-layer orientation. The first orientation is

*sandip.bhattacharya@sru.edu.in 


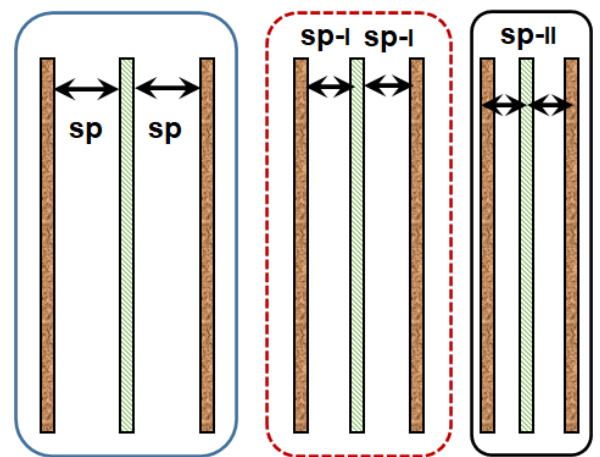

Fig. 2 - Schematic representation of tri-interconnect MLGNR interconnect model (top-view model) with different wire spacing $(\mathrm{sp}>\mathrm{sp}-\mathrm{I}>\mathrm{sp}-\mathrm{II})$

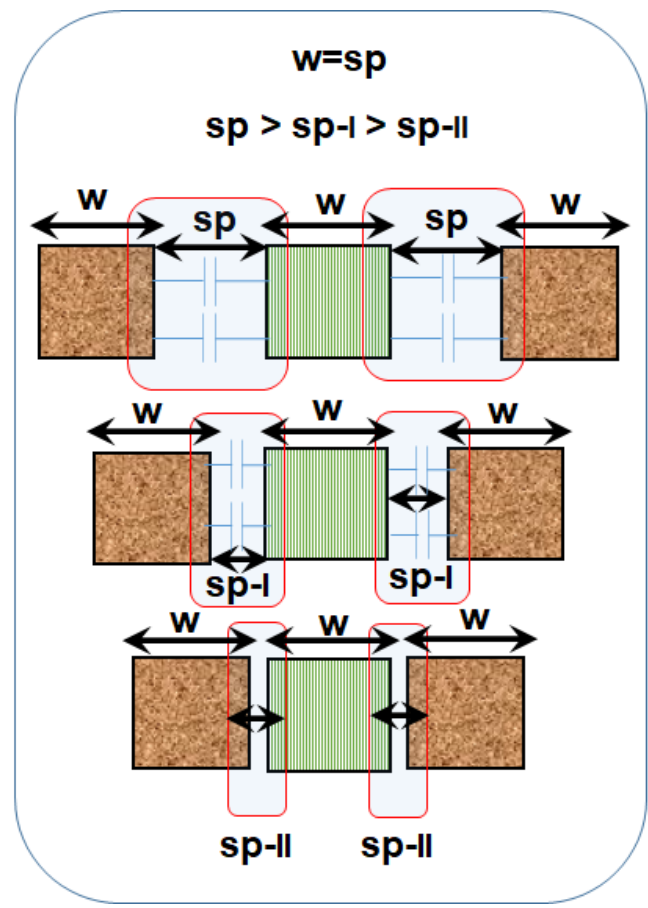

Fig. 3 - Schematic representation of tri-interconnect MLGNR interconnect model (side-view model) with different wire spacing $(\mathrm{sp}>\mathrm{sp}$-I $>$ sp-II)

called the Zigzag pattern, which always shows metallic properties, whereas the second orientation is called the Armchair and shows sometimes metallic and sometimes semiconducting properties. In this analysis, we considered only metallic properties for GNR-based interconnect modeling. Fig. 2 and Fig. 3 show the triinterconnect model with top-view and side-view for MLGNR interconnect with different wire spacing (sp, sp-I, sp-II). Fig. 4 shows the GNR tri-interconnect model with driver and load circuits. Three driver and load circuits are considered for coupling capacitance $\left(C_{C}\right)$ and crosstalk noise analysis. Each driver and load circuit is connected by GNR-based $R L C_{g}$ interconnect. Here, $R$ and $L$ are represented as line resistance and line capacitance, whereas $C_{g}$ is represented as ground capacitance. In GNR interconnect, the line resistance is distributed with the contact resistance $\left(R_{C}\right)$, as well as with the quantum resistance $\left(R_{Q}\right)$. Here, the line resistance is represented as $R=R_{C}+R_{Q}$. Similarly, the line capacitance $(C)$ is distributed with the quantum capacitance $\left(C_{Q}\right)$ and the electrostatic capacitance $\left(C_{E}\right)$. Here, the line resistance is represented as $C=C_{E}+C_{Q}$. For coupling capacitance $\left(C_{C}\right)$ analysis, we considered 1) the spatial variation between aggressor and victim net, 2) the MFP variation of MLGNR interconnect. For crosstalk noise analysis, we considered the input test pattern shown in Fig. 5. Using this test pattern, we can analyze the impact on the circuit performance. In Fig. 5, the primary condition for noise analysis is highlighted in red. When introducing aggressor net-1 and aggressor net-3, they switch from logic-0 to logic-1 and from logic- 1 to logic-0, respectively, while victim net is held at logic- 0 and logic- 1 , so, rise and fall of noise will appear at the output from the victim net. Rise and fall of noise (crosstalk noise) will degrade the circuit performance and, as a result, problems with circuit reliability will arise.

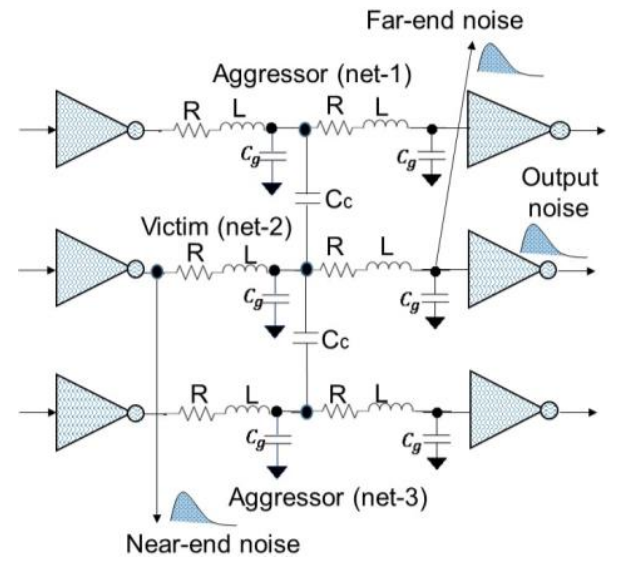

Fig. 4 - Schematic diagram of coupled interconnects

\begin{tabular}{|c|c|c|c|c|c|}
\hline \multirow{2}{*}{$\begin{array}{l}\text { Sl. } \\
\text { No }\end{array}$} & \multicolumn{2}{|c|}{ Aggressor Net } & \multirow{2}{*}{$\begin{array}{c}\text { Victim } \\
\text { Net }\end{array}$} & \multirow[t]{2}{*}{ Result } & \multirow[t]{2}{*}{ Impacts } \\
\hline & I & II & & & \\
\hline \multicolumn{6}{|c|}{ Crosstalk Delay Analysis } \\
\hline 1 & $0 \rightarrow 1$ & $0 \rightarrow 1$ & $0 \rightarrow 1$ & Decrease in rise time & Speed-up \\
\hline 2 & $0 \rightarrow 1$ & $0 \rightarrow 1$ & $1 \rightarrow 0$ & Inerease in fall time & Slow-down \\
\hline 3 & $1 \rightarrow 0$ & $1 \rightarrow 0$ & $0 \rightarrow 1$ & Increase in rise time & Slow-down \\
\hline 4 & $1 \rightarrow 0$ & $1 \rightarrow 0$ & $1 \rightarrow 0$ & Decrease in fall time & Speed-up \\
\hline \multicolumn{6}{|c|}{ Crosstalk Noise Analysis } \\
\hline 5. & $0 \rightarrow 1$ & $0-1$ & $1 \rightarrow 1$ & Overshoot & Reliability \\
\hline 6 & $0 \rightarrow 1$ & $0 \rightarrow 1$ & $0 \rightarrow 0$ & Rise Noise/Gliteh & Functionality \\
\hline 7 & $1 \rightarrow 0$ & $1 \rightarrow 0$ & $1 \rightarrow 1$ & Fall Noise/Glitch & Functionality \\
\hline$\overline{8}$ & & $1 \rightarrow 0$ & $0 \rightarrow 0$ & Undershoot & Reliability \\
\hline
\end{tabular}

Fig. 5 - Effects of crosstalk on the circuit performance

All experiments were performed in the MATLAB and T-SPICE simulation environment. The input voltage is applied to the driver side. In this analysis, the input voltage swings from 0 to $1 \mathrm{~V}$ and the pulse rise/fall time is assumed to be $50 \mathrm{ps}$. Driver and load are inverting buffers designed using the latest $95 \mathrm{~nm}$ ITRS-2011 technology node with SPICE models from the predictive technology model.

\section{RESULTS AND DISCUSSION}

In this section, we discuss about the coupling capacitance $\left(C_{C}\right)$ and its effect on crosstalk noise generation in next generation nano-integrated circuit design. Higher coupling capacitance generates a high noise peak, which 


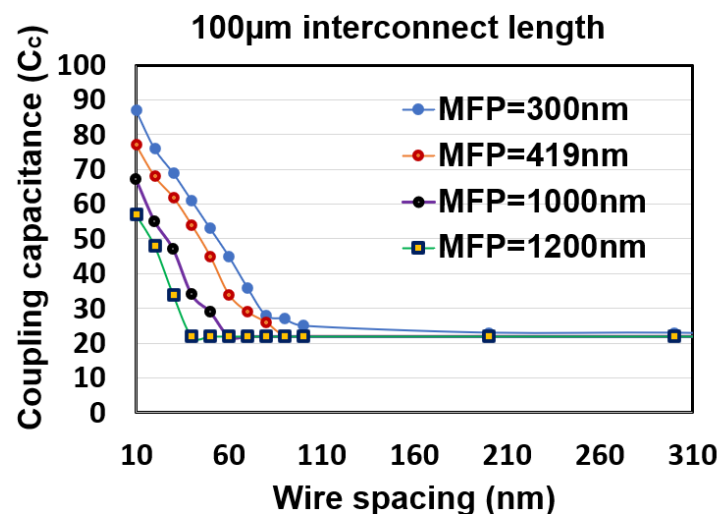

categorized as smaller $(100 \mu \mathrm{m})$, medium $(200 \mu \mathrm{m})$ and larger $(300 \mu \mathrm{m})$. For smaller length $(100 \mu \mathrm{m})$, the coupling capacitance $\left(C_{C}\right)$ shows $\sim 90 \mathrm{fF}$ at $300 \mathrm{~nm}$ MFP and $\sim 62 \mathrm{fF}$ at $1200 \mathrm{~nm}$ MFP with $10 \mathrm{~nm}$ wire spacing. Similarly, for medium length $(200 \mu \mathrm{m})$, the coupling capacitance $\left(C_{C}\right)$ shows $\sim 75 \mathrm{fF}$ at $300 \mathrm{~nm} \mathrm{MFP}$ and $\sim 60 \mathrm{fF}$ at $1200 \mathrm{~nm} \mathrm{MFP}$ with $10 \mathrm{~nm}$ wire spacing. Similarly, for larger length $(300 \mu \mathrm{m})$, the coupling capacitance $\left(C_{C}\right)$ shows $\sim 60 \mathrm{fF}$ at $300 \mathrm{~nm} \mathrm{MFP} \mathrm{and} \sim 48 \mathrm{fF}$ at $1200 \mathrm{~nm}$ MFP with $10 \mathrm{~nm}$ wire spacing. It is clear from the above analysis that a larger interconnect length $(300 \mu \mathrm{m})$ shows lower coupling capacitance compared to a smaller interconnect length $(100 \mu \mathrm{m})$. In Fig. 7 , it is observed that the higher MFP (1200 nm) shows a lower noise peak $(1.1 \mathrm{mV})$ compared to the smaller MFP $(300 \mathrm{~nm})$ with a noise peak of $3.65 \mathrm{mV}$.
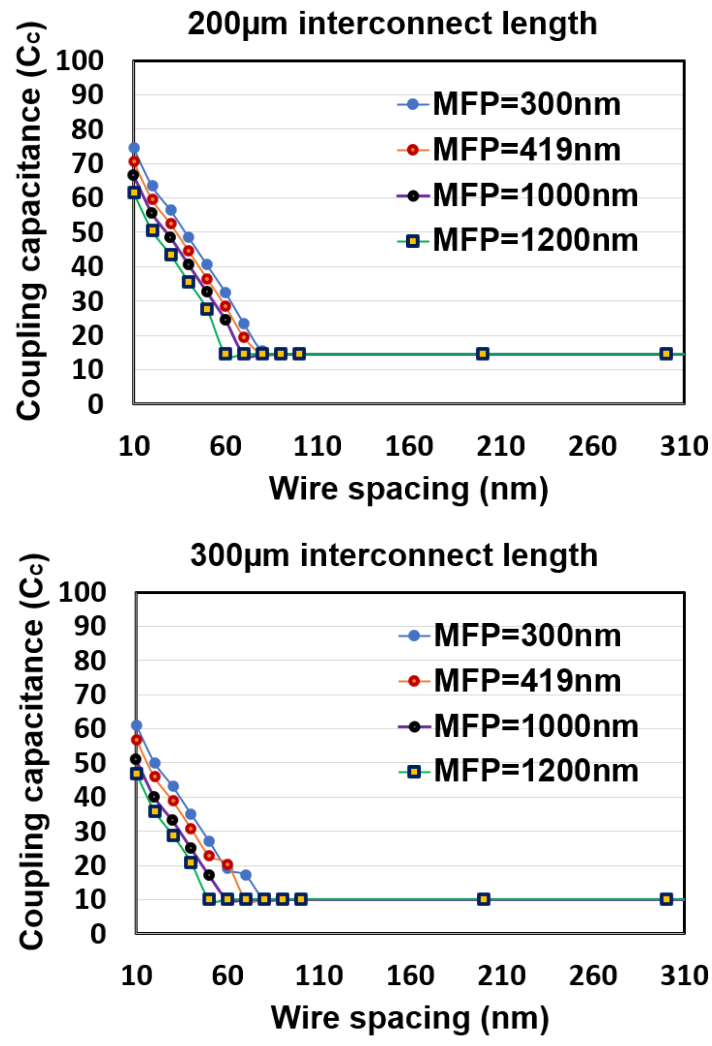

Fig. 6 - Wire spacing (nm) vs coupling capacitance (fF) with different MFP (300, 419, 1000 and $1200 \mathrm{~nm})$

may cause circuit reliability issues. Here we show how wire spacing and a higher GNR mean free path (MFP) can reduce the coupling capacitance $\left(C_{C}\right)$. As a result, much fewer noise peaks will be generated in the circuit, which can improve the circuit performance. Fig. 6 shows the coupling capacitance $\left(C_{C}\right)$ vs wire spacing $(\mathrm{nm})$ plot for three different interconnect lengths (100 to $300 \mu \mathrm{m})$. In this analysis, the interconnect length is

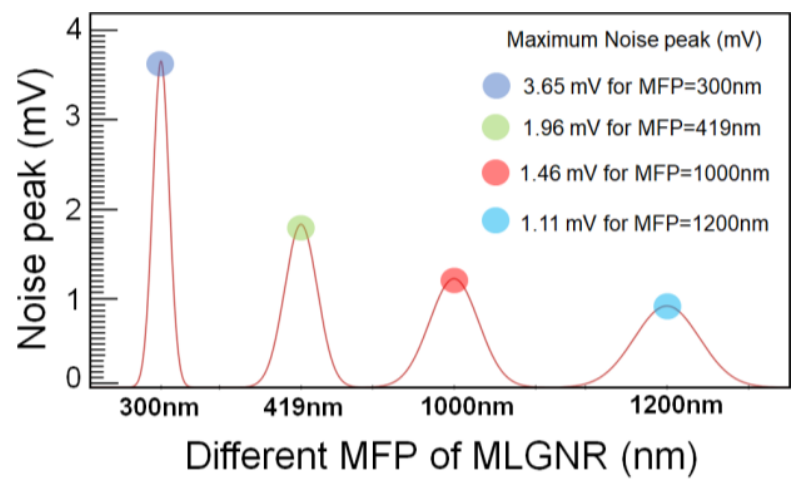

Fig. 7 - Crosstalk noise peak (mV) vs different MFP

\section{CONCLUSIONS}

In this work, we analyzed the effect of coupling capacitance $(C C)$ in GNR interconnects in a wide range of wire spacing at nanometer dimension, different interconnect lengths at $\mu \mathrm{m}$ dimension and different MFPs at nanometer dimension. It was observed that the higher coupling capacitance in an on-chip integrated circuit produces a significant amount of crosstalk noise, which can cause logic failure and reliability issues in a nanoelectronic circuit. From this analysis, it was also observed that a GNR interconnect with a higher MFP value shows less coupling capacitance that also results in reduced crosstalk noise, which can improve the circuit performance in terms of signal integrity.

\section{ACKNOWLEDGEMENTS}

This work was partially supported by SR University, Warangal, India, and DIT, Government of West Bengal, India, under VLSI Design Project.

\section{REFERENCES}

1. J. Cong, Z. Pan, IEEE Trans. Comput.-Aided Des. Integr. Circuits Syst. 21 No 3, 319 (2002).

2. D. Das, H. Rahaman, IEEE Trans. Nanotechnol. 10 No 6, 1362 (2011).

3. J. Cong, Z. Pan, L. He, C. Koh, K. Khoo, IEEE Int. Conf. Comput. Aided Des. (ICCAD) 478 (1997).

4. S. Kundu, S.T. Zachariah, Y. Chang, C. Tirumurti, IEEE Trans. Comput.-Aided Des. Integr. Circuits Syst. 24 No 12,

1909 (2005).

5. A. Vittal, L.H. Chen, M. Marek-Sadowska, K. Wang, S. Yang, IEEE Trans. Comput.-Aided Des. Integr. Circuits Syst. 18 No 12,1817 (1999).

6. A. Naeemi, J.D. Meindl, IEEE T. Electron Dev. 56 No 9, $1822(2009)$.

7. A. Naeemi, J.D. Meindl, IEEE T. Electron Dev. Lett. 28 No 5, 428 (2007). 
8. Chuan $\mathrm{Xu}$, Hong Li, Kaustav Banerjee, IEEE T. Electron Dev. 56 No 8, 1567 (2009).

9. Saeed Haji Nasiri, Mohammad Kazem Moravvej-Farshi,
Rahim Faez, IEEE T. Electron Dev. Lett. 31 No 12, 1458 (2010).

10. D. Das, H. Rahaman, Int. Symp. Electron. Syst. Design (ISED), 182 (2011).

\title{
Аналіз шуму перехресних перешкод за допомогою міжз'еднань графенової нанострічки шляхом зміни відстані між дротами та середнього вільного пробігу електронів
}

\author{
S. Bhattacharya ${ }^{1}$, S. Das ${ }^{2}$, S. Tayal ${ }^{1}$, J. Ajayan ${ }^{1}$, L.M.I. Leo Joseph ${ }^{1}$, D. Das ${ }^{3}$ \\ ${ }_{1}^{1}$ Department of Electronics and Communication Engineering, SR University, Warangal, Telangana, India \\ 2 School of VLSI Technology, Indian Institute of Engineering Science and Technology, Shibpur, India \\ ${ }^{3}$ Department of Electronics and Communication Engineering, Assam University, Silchar, India
}

Ми вивчаемо вплив емності зв'язку $\left(C_{C}\right)$ на шум перехресних перешкод у високопродуктивних вбудованих наноінтегральних схемах наступного покоління шляхом зміни відстані між дротами та середнього вільного пробігу (MFP) електронів між двома сусідніми мережами за допомогою міжз'єднань графенової нанострічки (GNR). Для аналізу емності зв'язку розглядаються міжз'еднання трьох багатошарових графенових нанострічок (MLGNR) з різною відстанню між дротами (від 10 до 300 нм) і різною довжиною міжз'еднання (100, 200 і 300 мкм). Помічено, що менший зазор між двома сусідніми мережами демонструе в 4-6 разів більшу емність зв'язку порівняно з більшою відстанню між дротами. 3 точки зору MFP електронів, більша величина MFP показуе на 20-34 \% меншу емність зв'язку порівняно з меншою величиною MFP. При аналізі шуму перехресних перешкод модель із трьома з'єднаннями зі схемою навантаження драйвера (тобто схемою CMOS-інвертора з мережею агресора та жертви) використовуеться для вивчення продуктивності з'еднань GNR з точки зору пікового шуму з різними можливими комбінаціями входів. Також помічено, що більша величина MFP міжз'еднання MLGNR демонструе менший пік шуму $(1,11$ мB з MFP = 1200 нм), тоді як менша величина MFP демонструе вищий пік шуму $(3,65$ мВ з $\mathrm{MFP}=300$ нм). Наведений аналіз корисний для проектування високошвидкісних інтегральних схем нового покоління, які е ефективними за площею та стійкими до шуму, з використанням з'єднань GNR.

Ключові слова: Графенова нанострічка (GNR), Середній вільний пробіг (MFP), Міжз'еднання, Температура, Шум перехресних перешкод. 